\title{
Chromium and nickel in Pteridium aquilinum from environments with various levels of these metals
}

\author{
Kamila Kubicka • Aleksandra Samecka-Cymerman • \\ Krzysztof Kolon • Piotr Kosiba • Alexander J. Kempers
}

Received: 14 May 2014 / Accepted: 23 July 2014 / Published online: 5 August 2014

(C) The Author(s) 2014. This article is published with open access at Springerlink.com

\begin{abstract}
Pteridium aquilinum is a ubiquitous species considered to be one of the plants most resistant to metals. This fern meets the demands for a good bioindicator to improve environmental control. Therefore, it was of interest to survey the accumulation of $\mathrm{Cr}$ and $\mathrm{Ni}$ in the rhizome and fronds of this species collected in Lower Silesia (SW Poland) of serpentinite rich in $\mathrm{Cr}$ and $\mathrm{Ni}$ and granite poor in these metals. Additionally, concentrations of $\mathrm{Cd}, \mathrm{Co}, \mathrm{Cr}, \mathrm{Cu}, \mathrm{Fe}, \mathrm{Mn}, \mathrm{Ni}$, $\mathrm{Pb}$, and $\mathrm{Zn}$ were measured in granite and serpentinite parent rocks, soils, and in P. aquilinum (rhizome and fronds). The experiment was carried out with rhizomes of ferns from both types of soils placed in pots supplemented with 50,100, and $250 \mathrm{mg} \mathrm{kg}^{-1}$ of $\mathrm{Cr}$ or $\mathrm{Ni}$ or both elements together. At a concentration of $250 \mathrm{mg} \mathrm{kg}^{-1}$ of $\mathrm{Cr}, \mathrm{Ni}$, or $\mathrm{Cr}+\mathrm{Ni}$, fronds (from granite or serpentinite origin) contained significantly higher $\mathrm{Cr}$ and $\mathrm{Ni}$ concentrations when both metals were supplied together. In the same concentration of $250 \mathrm{mg} \mathrm{kg}^{-1}$ of $\mathrm{Cr}, \mathrm{Ni}$, or $\mathrm{Cr}+\mathrm{Ni}$, rhizomes (from granite or serpentinite
\end{abstract}

Responsible editor: Elena Maestri

K. Kubicka $\cdot$ A. Samecka-Cymerman $(\bowtie) \cdot$ K. Kolon $\cdot$ P. Kosiba Department of Ecology, Biogeochemistry and Environmental Protection, Wrocław University, ul. Kanonia 6/8, 50-328 Wroclaw, Poland

e-mail: aleksandra.samecka@uni.wroc.pl

K. Kubicka

e-mail: pteridium@biol.uni.wroc.pl

K. Kolon

e-mail: krzysztof.kolon@uni.wroc.pl

P. Kosiba

e-mail: piotr.kosiba@uni.wroc.pl

\section{A. J. Kempers}

Institute for Water and Wetland Research, Department of

Environmental Science, Radboud University Nijmegen,

Heyendaalseweg 135, 6525 AJ Nijmegen, The Netherlands

e-mail: L.Kempers@science.ru.nl origin) contained significantly higher $\mathrm{Cr}$ and $\mathrm{Ni}$ concentrations when both metals were supplied separately. The explanation of metal differences in the joint accumulation of $\mathrm{Cr}$ and $\mathrm{Ni}$ on the rhizome or frond level needs further investigation. The lack of difference in $\mathrm{Cr}$ and $\mathrm{Ni}$ concentration in the rhizome and fronds between experimental $P$. aquilinum collected from granite and serpentinite soils may probably indicate that the phenotypic plasticity of this species is very important in the adaptation to extreme environments.

Keywords Bioaccumulation $\cdot$ Rhizome $\cdot$ Frond $\cdot$ Metal Granite $\cdot$ Serpentinite

\section{Introduction}

Ferns have often been associated with contaminated soils, particularly with mining operations (Samecka-Cymerman et al. 2012). Nevertheless, these plants have received less attention than vascular plants in relation to metal tolerance and accumulation (Kachenko et al. 2007; Niazi et al. 2012). Some fern species are important bioindicators of metalliferous soils or have the exceptional capability to hyperaccumulate some metals and have been used to decontaminate polluted sites (Kachenko et al. 2007; Leung et al. 2007; Zhang et al. 2012). Among fern species, Pteridium aquilinum (L.) Kuhn (bracken) is one of the world's most successful and widely dispersed species, the only terrestrial fern that dominates large tracts of land outside woodland in temperate climates (Marrs and Watt 2006; Chang et al. 2009). The P. aquilinum common in disturbed habitats is also recognized as one of the plants most resistant to metals (Chang et al. 2009). Therefore, this fern meets the demands for a good bioindicator which could be used to enable environmental control (Markert et al. 2003). The amount of any metal taken up by plants from contaminated soils has been suggested as being of central importance 
in assessing the risk of toxicity (Roy and Gunjan 2010). There is extensive information on the contamination of soils and plants by single metals; however, the combined pollution with these elements is a more common phenomenon in nature with mitigating or amplifying effects (Pivetz 2001; Haiyan 2003). Because xenobiotics like $\mathrm{Cr}$ and $\mathrm{Ni}$ are usually present together in polluted areas, a selection was made of model environments of granites (usually poor in both metals) and serpentinites typically with high concentrations of both $\mathrm{Ni}$ and Cr (Galardi et al. 2007; Samecka-Cymerman et al. 2009). Under experimental conditions, the single and combined accumulations of $\mathrm{Cr}$ and $\mathrm{Ni}$ in the fern were compared. It is well known that plants have a capacity to adapt to certain environmental conditions (Fernándèz et al. 2000). Therefore, $P$. aquilinum from granite areas should accumulate significantly less $\mathrm{Cr}$ and $\mathrm{Ni}$ than those from serpentinite sites which live on soils with an excess of these elements. The aim of this study was to experimentally compare the concentration of $\mathrm{Cr}$ and $\mathrm{Ni}$ in the rhizome and fronds of $P$. aquilinum from serpentinite and granite sites with supplementation of both elements separately and in combination. The following hypotheses were investigated: (1) combined concentrations of $\mathrm{Cr}$ and Ni supplied to $P$. aquilinum may cause suppressing effects on the sum of both toxicities and (2) P. aquilinum from serpentinite accumulates significantly more $\mathrm{Ni}$ and $\mathrm{Cr}$ than the same species from granite because it is adapted to soil containing increased concentrations of these metals.

\section{Materials and methods}

Study sites and collection of samples

In Lower Silesia (Fig. 1), a total of 22 sampling sites were selected, of which 11 on granites (sites 1-11) and 11 on serpentinites (sites 12-22). Soil profiles in those mountainous areas hardly accumulated organic material or developed a discernible A and B horizon because of erosion. Rockforming minerals contain most of the nutrients required by plants for growth and development. Ground-weathered rock has been proposed as a source of slow release of the elements to be utilized by plants (Harley and Gilkes 2000). Therefore, in each site, pieces of parent rock material were collected. At each site, five samples of the rhizome and fronds were collected randomly within a $25 \mathrm{~m} \times 25 \mathrm{~m}$ square. Each sample consisted of a mixture of three subsamples. As required by the rules set by the European Heavy Metal Survey (ICP Vegetation 2005), the collected ferns had not been exposed directly to canopy throughfall. Topsoil samples were also taken from each square, from a depth of 0 to $5 \mathrm{~cm}$. Each sample consisted of a mixture of three subsamples. Plant remains and stones were removed from the soil. The total number of rock, soil, and plant (rhizome and frond) samples was $22 \times 5=110$. The selected areas were relatively pollutionfree (WIOŚ 2009).

Plant, parent rock, and soil analysis

Fresh soil samples were used for the determination of $\mathrm{pH}_{\mathrm{H} 2 \mathrm{O}}$ and $\mathrm{pH}_{\mathrm{KCl}}$ potentiometrically (model: Hanna HI991300, Hanna Instruments Inc., Woonsocket (RI), USA) in a 1:2.5 soil- $\mathrm{H}_{2} \mathrm{O}$ and 1:2.5 soil-KCl ratios (Pansu and Gautheyrou 2006). Before analysis, rocks were crushed to a fine powder. Rhizomes were washed carefully for a few minutes and fronds for a few seconds in distilled water. Rock, soil, and plant samples were dried at $50{ }^{\circ} \mathrm{C}$ to constant weight. Soil samples were homogenized with a mortar and pestle after the coarse material was removed using a 2-mm sieve. Plant samples were homogenized to a fine powder in an IKA Labortechnik M20 laboratory mill. Dried soil and plant samples (300 mg of dry weight, in triplicate) were digested with $3 \mathrm{~mL}$ of nitric acid (ultra pure, $65 \%$ ) and $2 \mathrm{~mL}$ of perchloric acid (ultra pure, $70 \%$ ), and samples of rock powder (300 $\mathrm{mg}$ of dry weight, in triplicate) were digested in aqua regia in a CEM Mars 5 microwave oven. Samples were then diluted with deionized water to a total volume of $50 \mathrm{~mL}$, and the soil and plant digests were analyzed for $\mathrm{Fe}, \mathrm{Mn}$, and $\mathrm{Zn}$ using FAAS and $\mathrm{Cd}, \mathrm{Co}$, $\mathrm{Cr}, \mathrm{Cu}, \mathrm{Ni}$, and $\mathrm{Pb}$ using ETAAS with graphite furnace GF3000 (AVANTA PM Atomic Absorption Spectrophotometer from GBC Scientific Equipment). All elements were assayed against the atomic absorption standard solution from Sigma Chemical Co. and blanks containing the same matrix as the samples and were processed and analyzed as samples. Results of metal concentrations for the plants were calculated on a dry weight basis. The accuracy of the methods applied for the determination of the metal concentrations in plant and soil samples was checked against Certified Reference Materials: DC73348 LGC standards of bush branches and leaves and RTH 907 Dutch Anthropogenic Soil (Wageningen Evaluating Programs for Analytical Laboratories, WEPAL) (Table 1).

\section{Experimental design}

The toxicity of $\mathrm{Cr}$ and $\mathrm{Ni}$ ions on the fern (single metals as well as their combinations) was investigated. $\mathrm{Cr}$ and $\mathrm{Ni}$ as typical elements for serpentinites but also present in polluted environments were selected. From all the sampling sites analyzed, three on granite and three on serpentinite were chosen where the $\mathrm{Cr}$ and $\mathrm{Ni}$ concentration in the soil was equal to the average of all the investigated sites. Rhizomes of ferns were collected in March in a state of unfolded fronds (Zenkteler 1994). Rhizomes were cleaned from soil and washed in distilled water and then placed in threefold in pots filled with general potting mix soil according to Kachenko et al. (2007). Two groups of pots were established: one with "granite" 


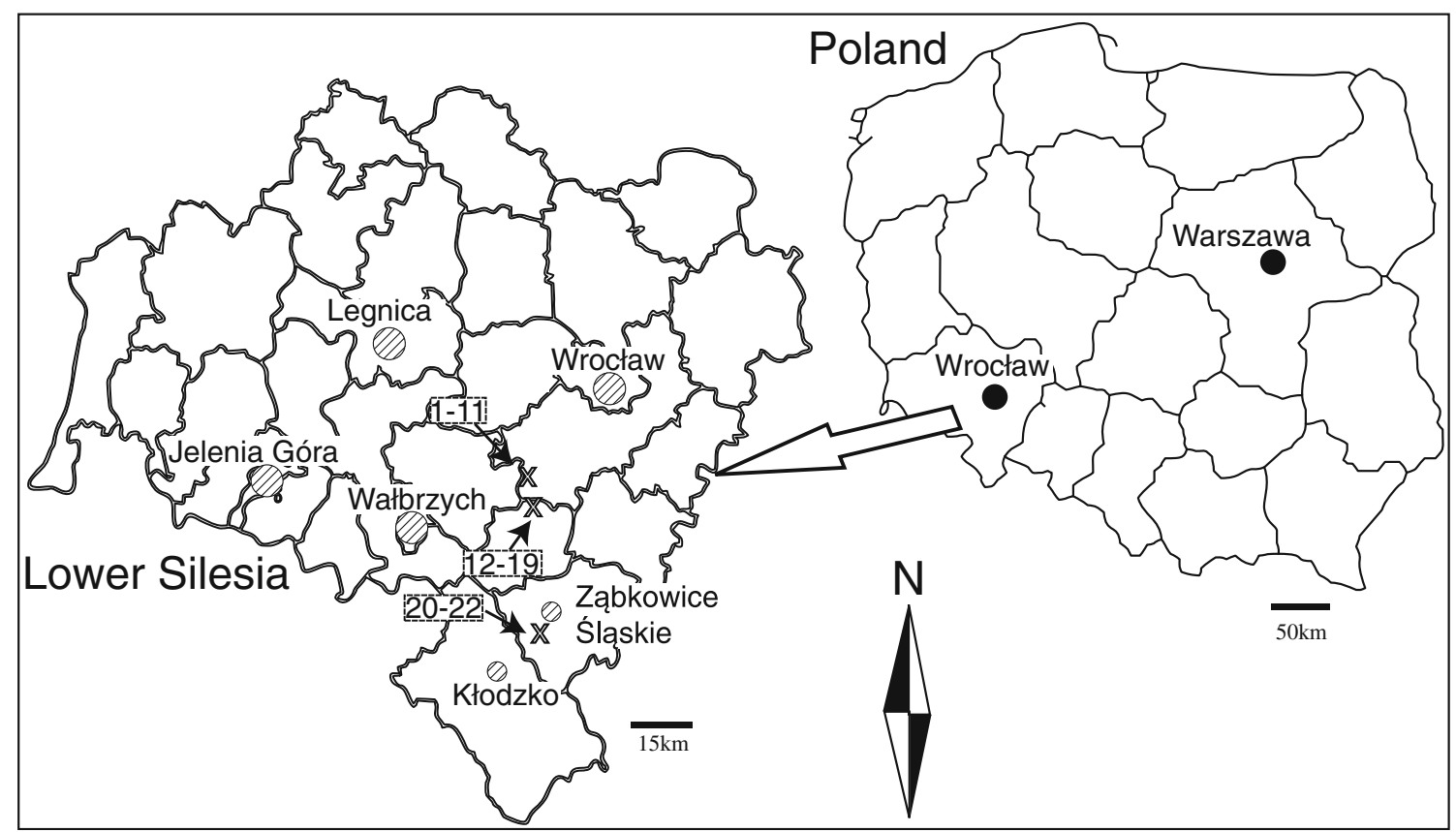

Fig. 1 Map showing study areas and sampling locations $(x)$

rhizomes and second with "serpentinite" rhizomes. Each of them was divided into three subgroups which received $\mathrm{Cr}, \mathrm{Ni}$, and mixture of $\mathrm{Cr}$ and $\mathrm{Ni}$, respectively. Metal salts were applied as 0 (control), 50, 100, and $250 \mathrm{mg} \mathrm{kg}^{-1}$ of dry weight

Table 1 Analysis of certified reference materials

\begin{tabular}{lllll}
\hline Element & $\begin{array}{l}\text { Certified } \\
\left(\mathrm{mg} \mathrm{kg}^{-1}\right)\end{array}$ & Found & $\begin{array}{l}\text { Recovery } \\
(\%)\end{array}$ & $\mathrm{CV}$ \\
\end{tabular}

Bush branches and leaves DC73348 LGC

$\begin{array}{lllll}\mathrm{Cd} & 0.14 & 0.13 \pm 0.006 & 92.86 & 4.62 \\ \mathrm{Co} & 0.39 & 0.38 \pm 0.01 & 97.44 & 2.63 \\ \mathrm{Cr} & 2.3 & 2.28 \pm 0.06 & 99.13 & 2.63 \\ \mathrm{Cu} & 5.2 & 5.05 \pm 0.12 & 97.12 & 2.38 \\ \mathrm{Fe} & 1,020 & 1,037 \pm 23 & 101.67 & 2.22 \\ \mathrm{Mn} & 58 & 58.33 \pm 1.5 & 100.57 & 2.57 \\ \mathrm{Ni} & 1.7 & 1.68 \pm 0.06 & 98.82 & 3.57 \\ \mathrm{~Pb} & 7.1 & 6.78 \pm 0.23 & 95.49 & 3.39 \\ \mathrm{Zn} & 20.6 & 20.81 \pm 0.32 & 101.02 & 1.54\end{array}$

Dutch Anthropogenic Soil RTH907

\begin{tabular}{lllll}
$\mathrm{Cd}$ & 2.18 & $2.22 \pm 0.08$ & 101.83 & 3.60 \\
$\mathrm{Cr}$ & 48.6 & $53.37 \pm 1.22$ & 109.81 & 2.29 \\
$\mathrm{Cu}$ & 121 & $119.63 \pm 1.75$ & 98.87 & 1.46 \\
$\mathrm{~Pb}$ & 318 & $311.4 \pm 7.53$ & 97.92 & 2.42 \\
$\mathrm{Zn}$ & 714 & $716 \pm 9.7$ & 100.28 & 1.35 \\
$\mathrm{Co}$ & 9.09 & $8.98 \pm 0.15$ & 98.79 & 1.67 \\
$\mathrm{Fe}$ & 16,600 & $17,130 \pm 630$ & 103.19 & 3.68 \\
$\mathrm{Mn}$ & 506 & $527 \pm 12$ & 104.15 & 2.28 \\
$\mathrm{Ni}$ & 27.9 & $26.99 \pm 1.03$ & 96.74 & 3.82 \\
\hline
\end{tabular}

of potting soil (for each metal) using $\mathrm{K}_{2} \mathrm{Cr}_{2} \mathrm{O}_{7}$ and $\mathrm{NiCl}_{2}$. The amounts were calculated by weight of elemental $\mathrm{Cr}$ and $\mathrm{Ni}$ (Kachenko et al. 2007). The hexavalent Cr(VI) species, considered the most toxic form, was selected (Shanker et al. 2005). Metal concentrations were chosen based on the average $\left(\sim 100 \mathrm{mg} \mathrm{kg}^{-1}\right)$ concentration of $\mathrm{Cr}$ and $\mathrm{Ni}$ in serpentinite soils of the examined sites. One lower $\left(50 \mathrm{mg} \mathrm{kg}^{-1}\right)$ and one higher concentration $\left(250 \mathrm{mg} \mathrm{kg}^{-1}\right)$ were added in the test series to study the mutual metal interference at other than the average concentration. Pots were arranged in a completely randomized experimental design, and there were three replicates for each treatment. The plants were raised in a glasshouse for 20 weeks, watered daily with deionized water, and no fertilizer was applied during the experimental period (Kachenko et al. 2007). Ferns were harvested after 20 weeks and separated into rhizomes and fronds. Rhizomes were carefully cleaned, and rhizomes and fronds were washed with distilled water. $\mathrm{Ni}$ and $\mathrm{Cr}$ concentrations were established as described above. The total amount of samples was $N=216$. The amount of replications was sufficient for proper statistical interpretation of the data.

\section{Statistical analysis}

Differences among sampling sites with respect to metal concentrations in rocks, soil, rhizome, and fronds were evaluated by one-way ANOVA on log-transformed data to obtain the normal distribution of features according to Zar (1999). The normality of the analyzed features was checked by means of Shapiro-Wilk's $W$ test, and the homogeneity of variances was checked after transformation using the Brown-Forsythe test. 
Element concentrations in experimental rhizomes and fronds from granite and serpentinite sites were compared with $t$ test (Zar 1999). All calculations were carried out using STATISTICA 10 software (StatSoft Inc. 2011).

\section{Results and discussion}

The $\mathrm{pH}$ of the examined soils may be classified as acidic, significantly lower for granite than for serpentinite (Table 3). The $\mathrm{pH}$ is an important factor which influences the trace element bioavailability by affecting speciation and solubility and the properties of biological surfaces (Lithner et al. 1995). According to Blake and Goulding (2002) and Liu et al. (2005), bioavailability of $\mathrm{Ni}$ and $\mathrm{Cr}$ increases as soil $\mathrm{pH}$ decreases. So a lower $\mathrm{pH}$ may result in a higher solubility of both metals in the examined soils. The ranges of metal concentrations in parent rock, soil, and ferns are displayed in Tables 2, 3 and 4. The parent rock, soil, and fern samples differed significantly in terms of the concentrations of the elements assessed (ANOVA, $P=0.05$ ). The concentrations (Table 2) of all the elements in granite were significantly lower than in serpentinite. This is in agreement with Galardi et al. (2007) that serpentine rocks are usually rich in $\mathrm{Cr}, \mathrm{Co}$, and $\mathrm{Ni}$. The concentration of $\mathrm{Co}, \mathrm{Fe}, \mathrm{Mn}$, and $\mathrm{Zn}$ in granite and serpentinite and of $\mathrm{Cr}$ and $\mathrm{Ni}$ in serpentinite was significantly higher than in overlaying soil $(t$ test, $P<0.05)$. Higher metal concentrations in parent rocks than in overlaying soil were also observed by Samecka-Cymerman et al. (2011) in Lower Silesia. Rhizomes and fronds from ferns of serpentinite soils contained significantly higher concentrations of $\mathrm{Cd}, \mathrm{Co}, \mathrm{Cr}$, and $\mathrm{Ni}$ and significantly lower concentrations of $\mathrm{Mn}$ than those from granite soils (Table 4). Thus, increased levels of metals in parent rocks and soils were reflected similarly in plants (Markert et al. 2003).

$P$. aquilinum sampled from serpentinite soils and those planted in the experimental pots contained significantly higher $(t$ test, $P<0.05$ ) concentrations of $\mathrm{Cr}$ and $\mathrm{Ni}$ in the rhizomes.
According to Fargašova (2012), the accumulation of $\mathrm{Cr}$ was higher in roots than in upper plant parts. The transport of $\mathrm{Ni}$ to shoots was at least twice as high as that of $\mathrm{Cr}$. Also, in this investigation, the concentration of $\mathrm{Ni}$ in fronds was at least twice as high as that of Cr. According to Oze et al. (2008), serpentinite vegetation suppresses $\mathrm{Cr}$ and $\mathrm{Ni}$ uptake into its aboveground biomass, and both elements are preferentially immobilized or sequestered in roots rather than leaves. This is probably a major mechanism for serpentinite vegetation to tolerate the elevated levels of metals in soils (Oze et al. 2008). Kachenko et al. (2007) also report that metal translocation was limited because of absorption and retention in roots, suggesting an exclusion mechanism as part of the ferns' tolerance to the metals supplied. Additionally, $\mathrm{Cr}$ compared to $\mathrm{Ni}$ is usually strongly bound in serpentinite soils, and the concentration of this element in roots was well below those in soils. However, nickel concentrations in plants usually reflect those in soil (Kabata-Pendias 2001). Plant tissue bioaccumulation factor (plant tissue element concentration)/(plant soil element concentration) of $\mathrm{Ni}$ for $P$. aquilinum from serpentinite and granite sites investigated by Samecka-Cymerman et al. (2009) exceeded 1, indicating that $P$. aquilinum is not an $\mathrm{Ni}$ excluder. There was also a significant positive Pearson correlation between the concentration of $\mathrm{Ni}$ in soil and $\mathrm{Ni}$ in P. aquilinum.

There was no difference in the concentration of $\mathrm{Ni}$ and $\mathrm{Cr}$ (applied both separately or together; all treatments) between the serpentinite and granite $P$. aquilinum rhizome and fronds $(t$ test, $P<0.05$ ). The exception was $\mathrm{Cr}$ concentration in fronds (Fig. 2) which was significantly higher in serpentinite than in granite ferns. This is in agreement with Żołnierz (2007) that serpentinite species frequently accumulate vast quantities of $\mathrm{Cr}$. This lack of difference in $\mathrm{Cr}$ and $\mathrm{Ni}$ concentration may probably indicate that the phenotypic plasticity of this species is very important in the adaptation to extreme environments and probably increases the survival of $P$. aquilinum in contaminated sites (Eränen 2008; Dunn and Rothwell 2012).

There was a significant increase in the concentration of $\mathrm{Cr}$ and $\mathrm{Ni}$ in the experimental ferns with higher applications of
Table 2 Minimum, maximum, mean and standard deviation (SD), and $t$ test of the concentration $\left(\mathrm{mg} \mathrm{kg}^{-1}\right)$ of metals in serpentinite and granite rock

\begin{tabular}{|c|c|c|c|c|c|c|c|c|c|}
\hline & \multicolumn{4}{|c|}{ Serpentinite } & \multicolumn{4}{|l|}{ Granite } & \multirow[t]{2}{*}{$P$ value } \\
\hline & Minimum & Maximum & Mean & SD & Minimum & Maximum & Mean & SD & \\
\hline $\mathrm{Cd}$ & 0.04 & 0.3 & 0.14 & 0.09 & 0.037 & 0.05 & 0.04 & 0.003 & $<0.01$ \\
\hline Co & 20 & 36 & 29 & 5.4 & 2.3 & 2.9 & 2.6 & 0.2 & $<0.001$ \\
\hline $\mathrm{Cr}$ & 171 & 412 & 232 & 89 & 2.2 & 6.5 & 4.1 & 1.4 & $<0.001$ \\
\hline $\mathrm{Cu}$ & 2.1 & 10 & 4.9 & 3 & 1.2 & 1.6 & 1.4 & 0.14 & $<0.01$ \\
\hline $\mathrm{Fe}$ & 28,305 & 60,548 & 50,953 & 12,034 & 7,176 & 11,857 & 9,467 & 1,714 & $<0.001$ \\
\hline $\mathrm{Mn}$ & 260 & 2,453 & 1,304 & 880 & 169 & 460 & 313 & 117 & $<0.01$ \\
\hline $\mathrm{Ni}$ & 696 & 1,273 & 920 & 200 & 1.5 & 3.4 & 2.4 & 0.6 & $<0.001$ \\
\hline $\mathrm{Pb}$ & 4.0 & 41 & 15 & 13 & 3.9 & 6.2 & 5.0 & 0.7 & $<0.05$ \\
\hline $\mathrm{Zn}$ & 26 & 94 & 56 & 24 & 31 & 42 & 35 & 3.2 & $<0.05$ \\
\hline
\end{tabular}


Table 3 Minimum, maximum, mean and standard deviation (SD), and $t$ test of $\mathrm{pH}_{\mathrm{H} 2 \mathrm{O}}, \mathrm{pH}_{\mathrm{KCl}}$, and the concentration $\left(\mathrm{mg} \mathrm{kg}^{-1}\right)$ of metals in soils of the serpentine and granite sites

\begin{tabular}{|c|c|c|c|c|c|c|c|c|c|}
\hline & \multicolumn{4}{|c|}{ Serpentinite } & \multicolumn{4}{|l|}{ Granite } & \multirow[t]{2}{*}{$P$ value } \\
\hline & Minimum & Maximum & Mean & SD & Minimum & Maximum & Mean & SD & \\
\hline $\mathrm{pH}_{\mathrm{H} 2 \mathrm{O}}$ & 4.0 & 4.7 & 4.4 & 0.2 & 3.6 & 4.4 & 4.0 & 0.2 & $<0.001$ \\
\hline $\mathrm{pH}_{\mathrm{KCl}}$ & 3.3 & 4.3 & 3.8 & 0.4 & 3.0 & 3.9 & 3.3 & 0.3 & $<0.001$ \\
\hline $\mathrm{Cd}$ & 0.09 & 0.97 & 0.35 & 0.25 & 0.02 & 0.2 & 0.09 & 0.06 & $<0.001$ \\
\hline Co & 2.9 & 31 & 11 & 9.9 & 0.4 & 3.1 & 1.6 & 0.8 & $<0.001$ \\
\hline $\mathrm{Cr}$ & 44 & 193 & 99 & 47 & 3.9 & 14 & 8.1 & 3.1 & $<0.001$ \\
\hline $\mathrm{Cu}$ & 3.5 & 13 & 7.1 & 3.1 & 3.0 & 8.7 & 5.4 & 1.8 & $<0.05$ \\
\hline $\mathrm{Fe}$ & 5,971 & 14,222 & 9,203 & 2,643 & 3,254 & 8,604 & 6,207 & 1,451 & $<0.001$ \\
\hline $\mathrm{Mn}$ & 42 & 950 & 262 & 274 & 56 & 142 & 97 & 25 & $<0.01$ \\
\hline $\mathrm{Ni}$ & 31 & 191 & 101 & 47 & 2.1 & 7.9 & 4.5 & 1.6 & $<0.001$ \\
\hline $\mathrm{Pb}$ & 22 & 87 & 43 & 23 & 16 & 74 & 30 & 14 & $<0.05$ \\
\hline $\mathrm{Zn}$ & 18 & 75 & 35 & 22 & 9 & 38 & 18 & 8.6 & $<0.01$ \\
\hline
\end{tabular}

both elements; however, a sharp increase in metal accumulation was observed at concentrations higher than $100 \mathrm{mg} \mathrm{kg}^{-1}$ (Fig. 2). According to Kachenko et al. (2007), such a phenomenon suggests breakdown in tolerance mechanisms and unrestricted metal transport. The results of the experiment were most spectacular for the $250 \mathrm{mg} \mathrm{kg}^{-1}$ level. In this concentration, rhizomes (both granite and serpentinite) contained significantly higher $\mathrm{Cr}$ and $\mathrm{Ni}$ concentrations when both metals were supplied separately (post hoc least significant difference (LSD), $P<0.05$ ) (Fig. 2). However, fronds (both granite and serpentinite) contained significantly higher concentrations of $\mathrm{Cr}$ and $\mathrm{Ni}$ when both metals were supplied together (post hoc LSD, $P<0.05$ ). According to Shah et al. (2010), Ni and Cr showed good correlation in both soils and plants in serpentinite areas. Baker et al. (1999) and SameckaCymerman et al. (1997) also suggest that the combined toxicity of both metals might be higher than the sum of the individual toxicities of each separate element. These results are in agreement with Shanker et al. (2005) that the toxicity of some elements changes in the presence of other metals and results in different effects comparing rhizomes with stems and leaves because of changing ratios. A $\mathrm{Cr} / \mathrm{Ni}$ different effect in fronds and rhizomes is therefore possible for metal uptake in P. aquilinum. Thus, $\mathrm{Cr}$ and $\mathrm{Ni}$ uptake in the fern appears to be controlled by their mutual concentrations (Ondo et al. 2012). According to Tomasik et al. (1995), the same Cr-Ni metal ions are listed as mitigating transfer from the soil to rhizome level and favoring transfer from the rhizome to fronds. The explanation of differences in the joint accumulation of $\mathrm{Cr}$ and $\mathrm{Ni}$ on the rhizome or frond level may probably be the competitive binding of $\mathrm{Cr}$ and $\mathrm{Ni}$ to the rhizome cell wall (Glick 2003). The interaction between ferns and rhizosphere microorganisms or mycorrhizal symbiosis which may influence the tolerance of $P$. aquilinum for metals should not be neglected
(Khan 2001). There is a possibility that both elements may be accumulated in the extrametrical hyphae or excluded by the symbiont (Göhre and Paszkowski 2006). However, to explain these differences in metal accumulation, further investigation is needed. The differences in the $\mathrm{Cr}$ accumulation behavior in the presence of $\mathrm{Ni}$ and other metals in plants need further investigation.

\section{Conclusions}

P. aquilinum sampled from serpentinite soils and those planted in the experimental pots contained significantly higher concentrations of both elements in the rhizome than in fronds. Grown at a concentration of $250 \mathrm{mg} \mathrm{kg}^{-1}$ of $\mathrm{Cr}$ or Ni in soil, fronds (both granite and serpentinite) contained significantly higher $\mathrm{Cr}$ and $\mathrm{Ni}$ concentrations when both metals were supplied together. At a concentration of $250 \mathrm{mg} \mathrm{kg}^{-1}$ of $\mathrm{Cr}$ or $\mathrm{Ni}$, rhizomes (both granite and serpentinite) contained significantly higher $\mathrm{Cr}$ and $\mathrm{Ni}$ concentrations when both metals were supplied separately. To explain these differences, further investigation is needed. In experimental ferns, there was no difference in the concentration of $\mathrm{Ni}$ and $\mathrm{Cr}$ (applied both separately or together; all treatments) between the serpentinite and granite $P$. aquilinum rhizome and fronds. The exception was $\mathrm{Cr}$ concentration in fronds which was significantly higher in serpentinite than in granite ferns. This lack of difference may probably indicate that the phenotypic plasticity of this species is very important in the adaptation to extreme environments and probably increases the survival of this fern in contaminated sites.

The results of this investigation may be applied in the bioindication of $\mathrm{Ni}$ and $\mathrm{Cr}$ in anthropogenic polluted environments. It contributes to the use of $P$. aquilinum in bioindication 
Table 4 Minimum, maximum, mean and standard deviation (SD), and $t$ test of the concentration ( $\mathrm{mg} \mathrm{kg}^{-1}$ ) of metals in rhizome and fronds of Pteridium aquilinum from the serpentinite and granite sites
Fig. $2 \mathrm{Cr}$ or $\mathrm{Ni}$ concentrations in rhizomes and in fronds of P. aquilinum from granite and serpentinite cultivated in experimental soils with concentrations of 50, 100, and $250 \mathrm{mg} \mathrm{kg}^{-1}$ of $\mathrm{Cr}$ and $\mathrm{Ni}$ applied separately or combined. $I \mathrm{Cr}$ in rhizome, $I I \mathrm{Cr}$ in fronds, $I I I \mathrm{Ni}$ in rhizome, $I V \mathrm{Ni}$ in fronds; $A$ serpentinite combined, $B$ serpentinite separate, $C$ granite combined, $D$ granite separate, mean, $\square$ standard error, $I$ confidence interval

\begin{tabular}{|c|c|c|c|c|c|c|c|c|c|}
\hline & \multicolumn{4}{|c|}{ Serpentinite } & \multicolumn{4}{|l|}{ Granite } & \multirow[t]{2}{*}{$P$ value } \\
\hline & Minimum & Maximum & Mean & SD & Minimum & Maximum & Mean & SD & \\
\hline \multicolumn{10}{|c|}{ Rhizome } \\
\hline $\mathrm{Cd}$ & 0.06 & 0.50 & 0.30 & 0.14 & 0.02 & 0.17 & 0.09 & 0.04 & $<0.001$ \\
\hline Co & 0.82 & 3.0 & 1.6 & 0.7 & 0.07 & 0.45 & 0.26 & 0.08 & $<0.001$ \\
\hline $\mathrm{Cr}$ & 0.70 & 11 & 6.1 & 3.4 & 1.4 & 2.5 & 1.9 & 0.32 & $<0.001$ \\
\hline $\mathrm{Cu}$ & 3.4 & 7.7 & 5.2 & 1.3 & 2.3 & 7.9 & 5.2 & 1.8 & $>0.05$ \\
\hline $\mathrm{Fe}$ & 140 & 282 & 205 & 45 & 82 & 271 & 154 & 52 & $<0.01$ \\
\hline $\mathrm{Mn}$ & 15 & 102 & 44 & 29 & 15 & 108 & 67 & 27 & $<0.01$ \\
\hline $\mathrm{Ni}$ & 11 & 29 & 19 & 5.7 & 1.9 & 8.1 & 3.7 & 1.4 & $<0.001$ \\
\hline $\mathrm{Pb}$ & 4.4 & 31 & 15 & 7.0 & 4.8 & 32 & 16 & 8.0 & $>0.05$ \\
\hline $\mathrm{Zn}$ & 20 & 42 & 30 & 5.9 & 9.2 & 33 & 23 & 8.0 & $<0.01$ \\
\hline \multicolumn{10}{|c|}{ Fronds } \\
\hline $\mathrm{Cd}$ & 0.10 & 0.45 & 0.29 & 0.09 & 0.02 & 0.14 & 0.08 & 0.03 & $<0.001$ \\
\hline Co & 0.12 & 1.9 & 0.82 & 0.64 & 0.08 & 0.82 & 0.36 & 0.25 & $<0.01$ \\
\hline $\mathrm{Cr}$ & 1.2 & 3.7 & 2.6 & 0.83 & 1.2 & 2.6 & 1.7 & 0.45 & $<0.001$ \\
\hline $\mathrm{Cu}$ & 2.2 & 8.5 & 4.8 & 2.0 & 2.8 & 7.7 & 4.1 & 1.2 & $>0.05$ \\
\hline $\mathrm{Fe}$ & 60 & 149 & 105 & 19 & 66 & 130 & 102 & 16 & $>0.05$ \\
\hline $\mathrm{Mn}$ & 59 & 358 & 165 & 85 & 61 & 803 & 325 & 227 & $<0.01$ \\
\hline $\mathrm{Ni}$ & 4.6 & 19 & 9.4 & 5.1 & 1.6 & 11 & 3.9 & 2.4 & $<0.001$ \\
\hline $\mathrm{Pb}$ & 0.67 & 7.6 & 4.4 & 1.1 & 1.2 & 6.0 & 3.5 & 1.2 & $<0.05$ \\
\hline $\mathrm{Zn}$ & 19 & 45 & 28 & 7.4 & 12 & 39 & 24 & 7.5 & $>0.05$ \\
\hline
\end{tabular}
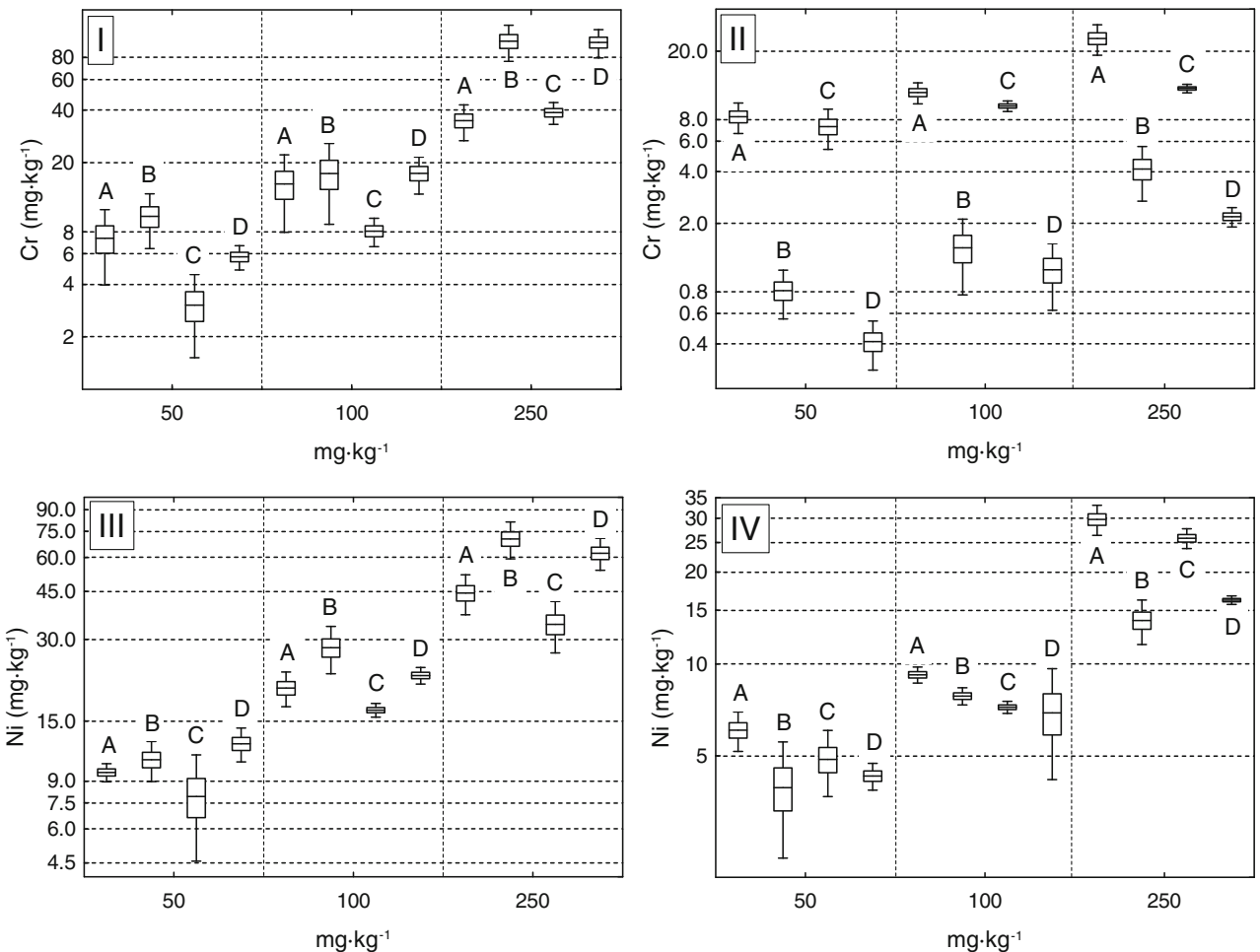
of the combined presence of $\mathrm{Cr}$ and $\mathrm{Ni}$, taking into account their changing effects at different ratios in the environment. Further investigation might supply assertion which biogeochemical condition will promote efficient phytoremediation by this species.

\section{Acknowledgments We thank Leszek Rudecki, MSc, for his help in the} chemical analyses.

Open Access This article is distributed under the terms of the Creative Commons Attribution License which permits any use, distribution, and reproduction in any medium, provided the original author(s) and the source are credited.

\section{References}

Baker AJM, McGrath SP, Reeves RD, Smith JAC (1999) Metal hyperaccumulator plants: a review of the ecology and physiology of a biological resource for phytoremediation of metalpolluted soils. In: Terry N, Bañuelos GS (eds) Phytoremediation of contaminated soil and water. CRC Press LLC, Boca Raton, pp 85-108

Blake L, Goulding KWT (2002) Effects of atmospheric deposition, soil $\mathrm{pH}$ and acidification on heavy metal contents in soils and vegetation of semi-natural ecosystems at Rothamsted Experimental Station, UK. Plant Soil 240:235-251

Chang JS, Yoon IH, Kim KW (2009) Heavy metal and arsenic accumulating fern species as potential ecological indicators in Ascontaminated abandoned mines. Ecol Indic 9:1275-1279

Dunn MT, Rothwell GW (2012) Phenotypic plasticity of the hydrasperman seed fern Tetrastichia bupatides Gordon (Lyginopteridaceae). Int J Plant Sci 173:823-834

Eränen JK (2008) Rapid evolution towards heavy metal resistance by mountain birch around two subarctic copper-nickel smelters. J Evol Biol 21:492-501

Fargašova A (2012) Plants as models for chromium and nickel risk assessment. Ecotoxicology 21:1476-1483

Fernándèz JA, Rey A, Carballeira A (2000) Differences in the responses of native and transplanted mosses to atmospheric pollution: a possible role of selenium. Environ Pollut 110:73-78

Galardi F, Mengoni A, Pucci S, Barletti L, Massi L, Barzanti R, Gabbrielli $\mathrm{R}$, Gonnelli C (2007) Intra-specific differences in mineral element composition in the Ni-hyperaccumulator Alyssum bertolonii: a survey of populations in nature. Environ Exp Bot 60:50-56

Glick BR (2003) Phytoremediation: synergistic use of plants and bacteria to clean up the environment. Biotechnol Adv 21:383-393

Göhre V, Paszkowski U (2006) Contribution of the arbuscular mycorrhizal symbiosis to heavy metal phytoremediation. Planta 223:11151122

Haiyan W (2003) Effect of Cd, Zn, and Pb compound pollution on celery in a ferric acrisol. Soil Sediment Contam 12:357-370

Harley AD, Gilkes RJ (2000) Factors influencing the release of plant nutrient elements from silicate rock powders: a geochemical overview. Nutr Cycl Agroecosyst 56:11-36

ICP Vegetation: Heavy metals in European mosses: 2005/2006 survey (2005) Monitoring manual. UNECE ICP Vegetation Coordination Centre. CEH Bangor, UK

Kabata-Pendias A (2001) Trace elements in soils and plants. CRC Press, Boca Raton

Kachenko AG, Singh B, Bhatia NP (2007) Heavy metal tolerance in common fern species. Aust J Bot 55:63-73
Khan AG (2001) Relationships between chromium biomagnification ratio, accumulation factor, and mycorrhizae in plants growing on tannery effluent-polluted soil. Environ Int 26:417-423

Leung HM, Ye ZH, Wong MH (2007) Survival strategies of plants associated with arbuscular mycorrhizal fungi on toxic mine tailings. Chemosphere 66:905-915

Lithner G, Holm K, Borg H (1995) Bioconcentration factors for metals in humic waters at different $\mathrm{pH}$ in the Ronnskar area (N. Sweden). Water Air Soil Pollut 85:785-790

Liu H, Probst A, Liao B (2005) Metal contamination of soils and crops affected by the Chenzhou lead/zinc mine spill (Hunan, China). Sci Total Environ 339:153-166

Markert BA, Breure AM, Zechmeister HG (2003) Definitions, strategies and principles for bioindication/biomonitoring of the environment. In: Markert BA, Breure AM, Zechmeister HG (eds) Bioindicators and biomonitors. Elsevier Science, Oxford, pp 3-39

Marrs RH, Watt AS (2006) Biological flora of the British Isles: Pteridium aquilinum (L.) Kuhn. J Ecol 94:1272-1321

Niazi NK, Singh B, Van Zwieten L, Kachenko AG (2012) Phytoremediation of an arsenic-contaminated site using Pteris vittata L. and Pityrogramma calomelanos var. austroamericana: a long-term study. Environ Sci Pollut Res 19:3506-3515

Ondo JA, Prudent P, Menye Biyogo R, Domeizel M, Vassalo L, Eba F (2012) Effects of $\mathrm{Cu}$ and $\mathrm{Zn}$ supplementation on metal uptake by Hibiscus sabdariffa. Res J Chem Sci 2:45-50

Oze C, Skinner C, Schroth AW, Coleman RG (2008) Growing up green on serpentine soils: biogeochemistry of serpentine vegetation in the Central Coast Range of California. Appl Geochem 23:3391-3403

Pansu M, Gautheyrou J (2006) Handbook of soil analysis: mineralogical, organic and inorganic methods. Springer-Verlag Berlin, Heidelberg

Pivetz B (2001) Phytoremediation of contaminated soil and ground water at hazardous waste sites. Ground Water Issue, U.S. Environmental Protection Agency, Office of Research and Development and Office of Solid Waste and Emergency Response EPA/540/S-01/500: 1-36

Roy BK, Gunjan PR (2010) Heavy metal accumulation and changes in metabolic parameters in Cajanas cajan grown in mine spoil. $\mathrm{J}$ Environ Biol 31:567-573

Samecka-Cymerman A, Marczonek A, Kempers AJ (1997) Bioindication of heavy metals in soil by liverworts. Arch Environ Contam Toxicol 33:162-171

Samecka-Cymerman A, Garbiec K, Kolon K, Kempers AJ (2009) Factor analysis of the elemental composition of Pteridium aquilinum from serpentine and granite soils as a tool in the classification of relations between this composition and the type of parent rock in the Śleża Massif in Lower Silesia, Poland. Environ Geol 58:509-514

Samecka-Cymerman A, Kolon K, Stankiewicz A, Kaszewska J, Mróz L, Kempers AJ (2011) Rhizomes and fronds of Athyrium filix-femina as possible bioindicators of chemical elements from soils over different parent materials in southwest Poland. Ecol Indic 11: $1105-1111$

Samecka-Cymerman A, Kolon K, Stankiewicz A, Mróz L, Kempers AJ (2012) Bioindicative comparison of the fern Athyrium distentifolium for trace pollution in the Sudety and Tatra mountains of Poland. Environ Monit Assess 184:6357-6365

Shah MT, Begum S, Khan S (2010) Pedo and biogeochemical studies of mafic and ultramfic rocks in the Mingora and Kabal areas, Swat, Pakistan. Environ Earth Sci 60:1091-1102

Shanker AK, Cervantes C, Loza-Taverac H, Avudainayagam S (2005) Chromium toxicity in plants. Environ Int 31:739-753

StatSoft Inc (2011) STATISTICA (data analysis software system), version 10. <www.statsoft.com>

Tomasik P, Magadza CM, Mhizha S, Chirume A, Zaranyika MF, Muchiriri S (1995) Metal-metal interactions in biological systems. Part IV. Freshwater snail Bulinus globosus. Water Air Soil Pollut 83: $123-145$ 
WIOŚ Wojewódzki Inspektorat Ochrony Środowiska (2009) Stan środowiska województwa dolnośląskiego w 2008 roku [State of environment in Lower Silesia in 2008]

Zar H (1999) Biostatistical analysis. In: Ryo T (ed.) fourth ed. PrenticeHall Inc., Upper Saddle River

Zenkteler E (1994) Paprocie [Ferns]. PWRiL, Warszawa
Zhang S, Li T, Huang H, Zou T, Zhang X, Yu H, Zheng Z, Wang Y (2012) $\mathrm{Cd}$ accumulation and phytostabilization potential of dominant plants surrounding mining tailings. Environ Sci Pollut Res 19:3879-3888

Żołnierz L (2007) Grasslands on serpentines in lower Silesia (SW Poland)-some aspects of their ecology. Zesz Nauk Uniw Przyrodniczego we Wrocławiu 557:1-231 